\title{
Bacillus subtilis improves maize tolerance to salinity
}

\author{
Nathalia Calhabeu Ferreira ${ }^{1}$ Rita de Cassia Lima Mazzuchelli ${ }^{1}$ Ana Claudia Pacheco ${ }^{1}$ \\ Fabio Fernando de Araujo ${ }^{1}$ Jadson Emanuel Lopes Antunes $^{2}$ Ademir Sergio Ferreira de Araujo ${ }^{2 *}$ \\ ${ }^{1}$ Universidade do Oeste Paulista (UNOESTE), Presidente Prudente, SP, Brasil. \\ ${ }^{2}$ Universidade Federal do Piauí (UFPI), Centro de Ciências Agrárias (CCA/UFPI), 64049-550, Teresina, PI, Brasil. E-mail: asfaruaj@yahoo.com.br. \\ "Corresponding author.
}

\begin{abstract}
The aim of this study was to evaluate the biochemical responses of maize, under saline stress, inoculated with Bacillus subtilis. Four levels of salinity were assessed: $0 \mathrm{mM}, 50 \mathrm{mM}, 100 \mathrm{mM}$, and $200 \mathrm{mM}$ of sodium chloride ( $\mathrm{NaCl}$ ). Saline conditions influenced negatively maize growth. However, the inoculation of B. subtilis improved the plant growth at highest level of NaCl. Chlorophyll content decreased while proline increased in inoculated plants submitted to highest salt levels. Also, B. subtilis increased the relative water content in leaves. B. subtilis improves the plant growth under salinity and ameliorates the biochemical damages in maize.
\end{abstract}

Key words: Zea mays; PGPB; biochemical responses; enzymes.

Bacillus subtilis melhora a tolerância do milho a salinidade

RESUMO: O objetivo do estudo foi avaliar a resposta bioquimica do milho, sob stresse salino, inoculado com Bacillus subtilis. Quatro niveis de salinidade foram avaliados: $0 \mathrm{mM}, 50 \mathrm{mM}, 100 \mathrm{mM}$ e $200 \mathrm{mM}$ de cloreto de sódio (NaCl). Condições salinas influenciaram negativamente o crescimento do milho. Entretanto, a inoculação com B. subtilis melhorou o crescimento das plantas no maior nivel de NaCl. O teor de clorofila decresceu enquanto que a prolina aumentou em plantas submetidas aos niveis salinos e inoculadas com $B$. subtilis. B. subtilis também aumentou o conteúdo de agua foliar. A inoculação com B. subtilis promove melhor crescimento das plantas sob salinidade e atenua os danos bioquímicos no milho.

Palavras-chave: Zea mays; $B P C P$; resposta bioquímica; enzimas.

Salinity of agricultural soils is nowadays one the most important problem worldwide since this process causes losses of crop productivity every year. Although, this process influences the plant growth and affects its physiological responses, plant growth-promoting bacteria (PGPB) can ameliorate some negative effects of salinity on plant growth (SHRISVASTAVA \& KUMAR, 2015). The PGPBs contribute to plant growth through of direct and indirect mechanisms, such as nitrogen fixation and plant hormones, also promoting tolerance to plants on abiotic stress (GLICK, 2012). Considering abiotic stress promoted by salinity, studies have shown that some specific bacteria can help plants to survive under high salinity conditions, such as Pseudomonas fluorescens (SARAVANAKUMAR \& SAMIYAPPAN, 2007), and P. putida (GAMALERO et al., 2010). Although, these previous studies have stated, basically, Pseudomonas as the most important species for helping plants against the salt stress, B. subtilis can also produce substances, such as enzymes and volatile organic compounds (VOCs), for stress tolerance (MEDEIROS et al., 2011). FARAG et al. (2006) reported that B. subtilis releases some VOCs that promoted plant growth and abiotic stress tolerance in Arabidopsis. However, it is unclear how is the influence of $B$. subtilis on the responses of maize under salt stress. Therefore, we investigated the effect of salinity on biochemical activity and growth of maize inoculated with B. subtilis under controlled conditions.

Seeds of Zea mays (SYN 7205) were sterilized and sowed into plastic pots containing $15 \mathrm{~kg}$ of Paleudult soil $(\mathrm{pH}$ in water - 6.6; organic matter $-10 \mathrm{~g} \mathrm{dm}^{-3}$; P-68.8mg dm${ }^{-3} ; \mathrm{H}+\mathrm{Al}, \mathrm{K}, \mathrm{Ca}$ and $\mathrm{Mg}-$ 
17.6, 3, 25.9 and $7.2 \mathrm{mmol}_{\mathrm{c}} \mathrm{dm}^{-3}$, respectively). The strain of $B$. subtilis used in this was PRBS-1. This strain was isolated and characterized by ARAUJO et al. (2005a). The experiment was carried out under greenhouse condition in a completely randomized design with four replicates. Treatments consisted of four $\mathrm{NaCl}$ concentrations $(0 \mathrm{mM}, 50 \mathrm{mM}, 100 \mathrm{mM}$ and $200 \mathrm{mM}$ diluted with water) with and without inoculation of $B$. subtilis. The rhizobacteria in the concentration of $10^{9}$ cells per $\mathrm{mL}$ was inoculated by using $0.1 \mathrm{~mL}$ of suspension per seed. At 10 days after plant emergence, saline solutions were applied by irrigation three times a week during a period of 30 days. The volume of solution added in each irrigation was calculated according to gravimetric method based on evapotranspiration. The measurement of Chlorophyll (SPAD unit) was assessed 37 days after plant sowing through of a portable chlorophyll meter. Plants were collected 45 days after plant sowing for evaluation of plant biomass. Samples of fresh leaves were collected for evaluation of proline, peroxidase, and relative water content. Proline concentration was evaluated according to BATES et al. (1973). The evaluation of relative water content (RWC) was proceeded using the values of fresh mass weight (MF), turgid (MT) and dry matter (DM) from leaf discs, using the formula (BARRS \& WEATHERLEY, 1962): RWC $=($ MF-MS $) /($ MTMS) $\times 100 \%$. Guaiacol Peroxidase (GPX) was measured with guaiacol according to ARAUJO et al. (2005b). Data were compared through analysis of variance (ANOVA). The means were compared by using least significant difference values calculated at the $5 \%$ level.
Saline conditions affected negatively the plant dry weight in both non-inoculated and inoculated plants, with average reductions of $85 \%$ and $95 \%$ for shoot and root, respectively, in the highest level of salinity (Table 1). However, at the treatments without salinity (control) and with the highest salt concentration, the inoculation of $B$. subtilis promoted higher shoot and root dry weight than treatments without B. subtilis. Similarly, the chlorophyll indices were higher in plants inoculated with B. subtilis in the treatments without salts and with the highest salt concentration (Figure 1A). At the highest $\mathrm{NaCl}$ concentration $(200 \mathrm{mM})$, proline concentration increased while RWC decreased in non-inoculated plants. Inoculation of $B$. subtilis promoted a reduction in proline concentration as compared with plant without B. subtilis (Figure 1B). In contrast, RWC decreased about $80 \%$ from control to the highest salts concentration in non-inoculated plants (Figure 1C). However, at the highest salts concentration, the presence of B. subtilis promoted an increase on RWC as compared with plant without B. subtilis. There was not negative or positive effect of the presence of $B$. subtilis on peroxidase concentration in maize (Figure 1D).

These results showed that $B$. subtilis promotes positive influence on plant growth under normal conditions (without salinity). However, it is important to report that, under salts stress condition, B. subtilis showed ability for inducing plants tolerance to high salt concentration. Usually, under high salinity condition, plants increase the biosynthesis

Table 1 - Influence of inoculation with B. subtilis on the growth of maize in at four different levels of salinity.

\begin{tabular}{|c|c|c|c|c|}
\hline \multirow[t]{2}{*}{ Salinity $(\mathrm{NaCl})$} & \multirow[t]{2}{*}{ B. subtilis } & \multicolumn{3}{|c|}{ - } \\
\hline & & Shoot & Root & Total \\
\hline \multirow[t]{2}{*}{$0 \mathrm{mM}$} & Without & $28.2 \pm 2.5^{\mathrm{b}}$ & $37.7 \pm 4.3^{\mathrm{b}}$ & $65.9 \pm 6.7^{\mathrm{b}}$ \\
\hline & With & $33.4 \pm 2.6^{\mathrm{a}}$ & $48.2 \pm 3.9^{\mathrm{a}}$ & $81.6 \pm 7.9^{\mathrm{a}}$ \\
\hline \multirow[t]{2}{*}{$50 \mathrm{mM}$} & Without & $17.2 \pm 1.9^{\mathrm{a}}$ & $9.58 \pm 1.11^{\mathrm{a}}$ & $26.8 \pm 2.7^{\mathrm{a}}$ \\
\hline & With & $15.5 \pm 1.7^{\mathrm{a}}$ & $10.5 \pm 1.31^{\mathrm{a}}$ & $26.0 \pm 2.4^{\mathrm{a}}$ \\
\hline \multirow[t]{2}{*}{$100 \mathrm{mM}$} & Without & $15.3 \pm 2.1^{\mathrm{a}}$ & $9.62 \pm 1.33^{\mathrm{a}}$ & $24.9 \pm 2.2^{\mathrm{a}}$ \\
\hline & With & $16.1 \pm 2.5^{\mathrm{a}}$ & $7.10 \pm 1.24^{\mathrm{a}}$ & $23.2 \pm 2.1^{\mathrm{a}}$ \\
\hline \multirow[t]{2}{*}{$200 \mathrm{mM}$} & Without & $2.65 \pm 0.98^{b}$ & $1.83 \pm 0.32^{\mathrm{a}}$ & $2.65 \pm 0.88^{b}$ \\
\hline & With & $6.52 \pm 2.40^{\mathrm{a}}$ & $2.60 \pm 0.57^{\mathrm{a}}$ & $9.12 \pm 2.44^{\mathrm{a}}$ \\
\hline
\end{tabular}

Means in the column followed by distinct letters differ by the Tukey test at $5 \%$. 
of ethylene, as a signal of stress, by production of 1-aminocyclopropane-1-carboxylic acid (ACC) decreasing their growth (GLICK, 2012). However, ACC can also be metabolized by bacteria through ACC-deaminase, favoring the plant growth and ameliorating the stress (VAN DE POEL; VAN DER STRAETEN, 2014). Specifically, the isolate of $B$. subtilis used in this study was already characterized as an ACC deaminase producer (MOREIRA \& ARAUJO, 2013) and it may have contributed for better growth of maize plants under high salinity. Results showed a decrease of about $50 \%$ in the chlorophyll content in plants grown under the highest salt concentration, and it suggests that high salinity decreases the chlorophyll content in plants of maize. However, plant inoculated with $B$. subtilis presented better tolerance to salts and showed higher chlorophyll content than non-inoculated plants. Similarly, MAHMOUD et al. (2017) verified the effect of salinity on wheat and reported an increase in chlorophyll content in inoculated plants submitted to $200 \mathrm{mM}$ of $\mathrm{NaCl}$. This result may be associated with the better condition of water in the leaves in the inoculated plants under high salinity (Figure 1C). The lower water content in leaves is a signal of salts stress (FAHAD et al., 2015), and B. subtilis could ameliorate this condition contributing for increasing water in leaves. It agrees with VARDHARAJULA et al. (2011) who reported that the inoculation of maize with Bacillus spp. alleviates the negative effect of drought stress by increasing relative water content in plants.

At the highest salinity concentration $(200 \mathrm{mM})$ there was an increase in the concentration of proline in treatment without $B$. subtilis as compared with the presence of Bacillus. Its accumulation in plants provides protection against salinity and drought stress (SINGH et al., 2014). It can be associated with content of water in leaves since there is a strong correlation between water potential in leaves and the concentration of proline (NADEEM et al., 2010). It means that proline is important for maintenance of water in leaves. However, the presence of $B$. subtilis decreased the concentration of proline under highest salinity concentration and it was also observed by NADEEM et al. (2010) in wheat under salts stress. In this study, there was an increase in the
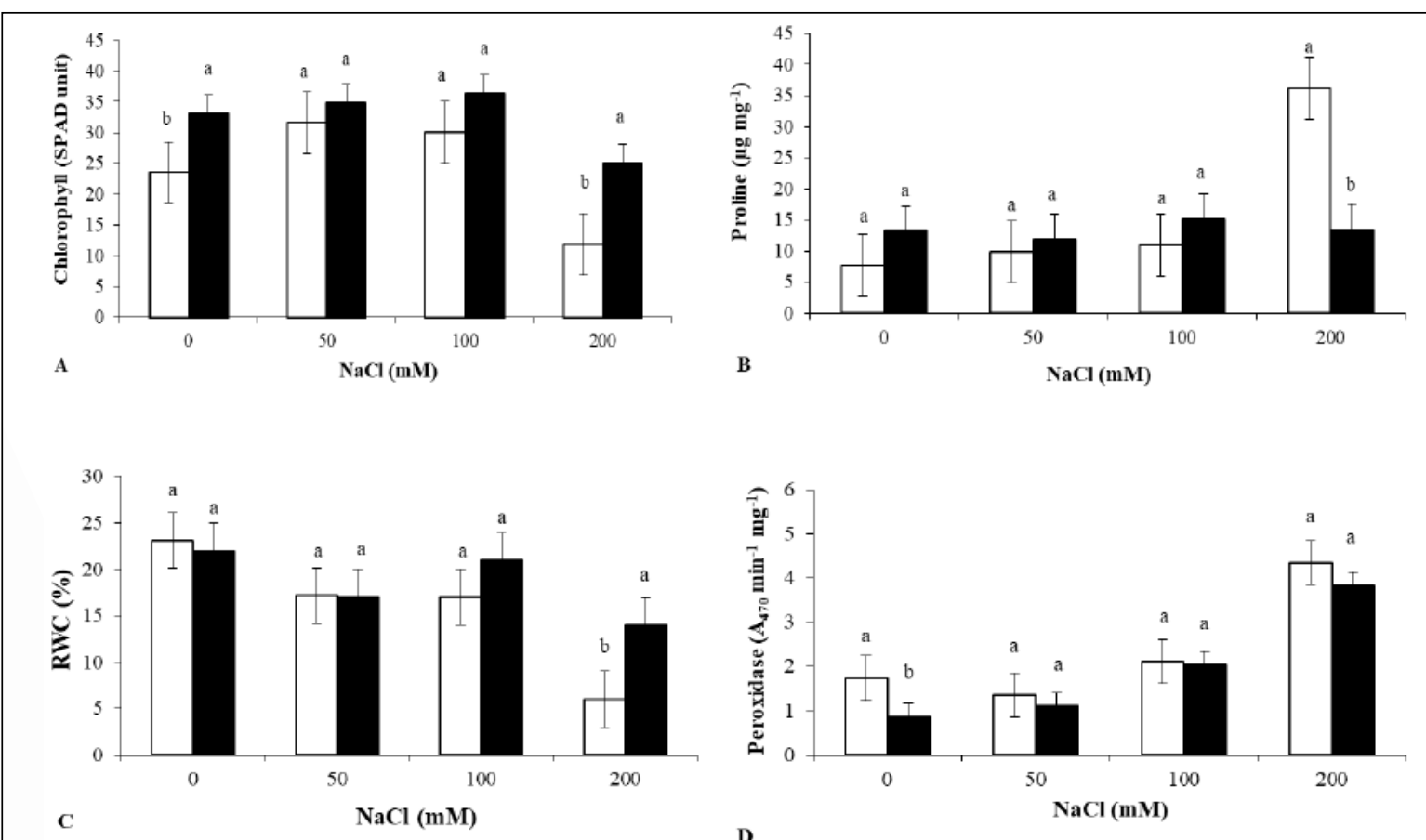

Figure 1 - Influence of inoculation with B. subtilis on chlorophyll (A), proline content (B), RWC (C), and peroxidase (D) in maize submitted to four different levels of salinity. White bars - without B. subtilis; black bars - with B. subtilis. 
peroxidase activity when the plants were submitted to salts stress. However, there was not reported positive effect of B. subtilis on the peroxidase activity under salts stress. Although, results showed lower activity of peroxidase in inoculated plants in soil without salinity, it confirms that PGPBs can collaborate with plants in the decrease in peroxidase activity, so decreasing the oxidative damages, as also reported in maize inoculated with Pseudomonas spp. (SANDHYA et al., 2010). Results suggested that B. subtilis presents significant positive influence on growth and biochemical activity of plants under salts stress. This study showed that the inoculation of B. subtilis promoted better plant growth under salinity condition. Amelioration of biochemical damages in maize with inoculation of $B$. subtilis indicates that this PGPB present potential for promoting tolerance of plants to salinity.

\section{DECLARATION OF CONFLICTING OF INTERESTS}

The authors declare no conflict of interest. The founding sponsors had no role in the design of the study; in the collection, analyses, or interpretation of data; in the writing of the manuscript, and in the decision to publish the results.

\section{REFERENCES}

ARAUJO, F.F. et al. Phytohormones and antibiotics produced by $B$. subtilis and their effects on seed pathogenic fungi and on soybean root development. World Journal of Microbiology \& Biotechnology, v.21, p.1639-1645, 2005a. <https://link.springer.com/content/ pdf/10.1007\%2Fs11274-005-3621-x.pdf>. Accessed: Mar. 25, 2018.

ARAUJO, A.S.F.; MONTEIRO, R.T.R.; CARDOSO, P.F. Composted textile sludge on soybean and wheat seedlings. Pesquisa Agropecuaria Brasileira, v.40, p.549-554, 2005b. <http://www. scielo.br/scielo.php?script $=$ sci_arttext\&pid $=$ S0100204X200500060 0004\&lng=en\&nrm=iso\&tlng=pt $>$. Accessed: Dec. 12, 2017.

BARRS, H.D.; WEATHERLEY, P.E. A re-examination of the relative turgidity technique for estimating water deficit in leaves. Australian Journal of Biological Science, v.15, p.413-428, 1962.

BATES, L.S. et al. Rapid determination of free proline for water-stress studies. Plant \& Soil, v.39, p.205-207, 1973. <https://link.springer. com/article/10.1007/BF00018060>. Accessed: Aug. 12, 2017.

FAHAD, S. et al. Phytohormones and plant responses to salinity stress: a review. Plant Growth Regulation, v.75, p.391-404, 2015. $<$ https://ink.springer.com/article/10.1007/s10725-014-0013-y >. Accessed: Aug. 13, 2017. doi: 10.1007/s10725-014-0013-y.

FARAG, M.A. et al GC-MS SPME profiling of rhizobacterial volatiles reveals prospective inducers of growth promotion and induced systemic resistance in plants. Phytochemistry v.67, p.2262-2268, 2006. <http:// www.sciencedirect.com/science/article/pii/S0031942206004250>. Accessed: Aug. 12, 2017. doi: 10.1016/j.phytochem.2006.07.021.
GAMALERO, E. et al Interactions between Pseudomonas putida UW4 and Gigaspora rosea BEG9 and their consequences for the growth of cucumber under salt stress conditions. Journal Applied Microbiology, v.108, p.236-245, 2010. <http:/onlinelibrary.wiley.com/doi/10.1111/ j.1365-2672.2009.04414.x/abstract>. Accessed: Aug. 12, 2017.

GLICK, B.R. Plant Growth-Promoting Bacteria: Mechanisms and Applications. Scientifica, v.18, e963401, 2012. <https://www. hindawi.com/journals/scientifica/2012/963401/>. Accessed: Aug. 13, 2017. doi: $10.6064 / 2012 / 963401$.

MAHMOUD, O.M.B. et al. Response to salt stress is modulated by growth-promoting rhizobacteria inoculation in two contrasting barley cultivars Acta Physiologiae Plantarum, v.39, p.120-129, 2017. $<$ https://link.springer.com/article/10.1007\%2Fs11738-017-2421-x> Accessed: Mar. 26, 2018.

MEDEIROS, F.H. et al. Transcriptional profiling in cotton associated with $B$. subtilis (UFLA285) induced biotic-stress tolerance. Plant \& Soil, v.347, p.327-337, 2011. <https://link.springer.com/ article/10.1007/s11104-011-0852-5>. Accessed: Aug. 12, 2017.

MOREIRA, A.L.L.; Araújo, F.F. Bioprospection of Bacillus spp. as potential growth promoters in Eucalyptus urograndis. Revista Árvore, v.37, p.933-943, 2013. <http://www.scielo.br/pdf/rarv/ v37n5/16.pdf $>$. Accessed: Aug. 15, 2017. doi: 10.1590/S010067622013000500016.

NADEEM, S.M. et al. Rhizobacteria capable of producing ACCdeaminase may mitigate salt stress in wheat. Soil Science Society American Journal,v.74, p.533-542,2010.<https://dl.sciencesocieties. org/publications/sssaj/abstracts/74/2/533? access $=0 \&$ view $=$ pdf $>$. Accessed: Aug. 15, 2017. doi: 10.2136/sssaj2008.0240.

SANDHYA, V. et al. Effect of plant growth promoting Pseudomonas spp. on compatible solutes. antioxidant status and plant growth of maize under drought stress. Plant Growth Regulation, v.62, p.21-30，2010. <https://link.springer.com/ article/10.1007/s10725-010-9479-4>. Accessed: Aug. 12, 2017. doi: 10.1007/s10725-010-9479-4.

SARAVANAKUMAR, D.; SAMIYAPPAN, R. ACC deaminase from Pseudomonas fluorescens mediated saline resistance in groundnut (Arachis hypogea) plants. Journal of Applied Microbiology, v.102, p.1283-1292, 2007. <https://onlinelibrary.wiley.com/doi/pdf/ 10.1111/j.1365-2672.2006.03179.x>. Accessed: Aug. 13, 2017. doi: $10.1111 / \mathrm{j} .1365-2672.2006 .03179 . \mathrm{x}$.

SINGH, M. et al. Proline and salinity tolerance in plants. Biochemical Pharmacology, v.3, e170, 2014. <https://www.omicsonline. org/open-access/proline-and-salinity-tolerance-in-plants-21670501.1000e170.pdf $>$. Accessed: Mar. 25, 2018.

VAN DE POEL, B.; VAN DER STRAETEN, D. 1-aminocyclopropane-1-carboxylicacid (ACC) in plants: more than just the precursor of ethylene. Frontiers in Plant Science, v.5, p.111, 2014. doi: 10.3389/fpls.2014.00640. Accessed: Mar. 26, 2018.

VARDHARAJULA, S. et al. Drought-tolerant plant growth promoting Bacillus spp: effect on growth, osmolytes, and antioxidant status of maize under drought stress. Journal of Plant Interaction, v.6, p.1-14, 2011. <https://www.tandfonline.com/doi/abs/10.1080/17 429145.2010.535178> Accessed: Mar. 26, 2018. 